\title{
A RareLocation of Leiomyoma
}

MF Cevher Akdulum ${ }^{1}$, M Çaltekin ${ }^{2}$

The Editor,

Sir,

A 44 years old woman presented with swelling in vulva for a year. Cause of vulvar swelling is generally Bartolins abscess or cyst(1). We must think different causes every time. It's an interesting and rare case for about location of leiomyoma. Although leiomyoma or fibroid is found frequently in uterus it is a rare entity in vulva, ovaries, urethra and urinary bladder $(2,3)$. I emphasize here that such lesions should be removed. Because malign and benign vulvar lesions have got similar apperances on physical examination(4). Hystopathologic examination is important. Deep surgical excision should be performed due to the risk of malignancy and recurrence (5) [Figure].

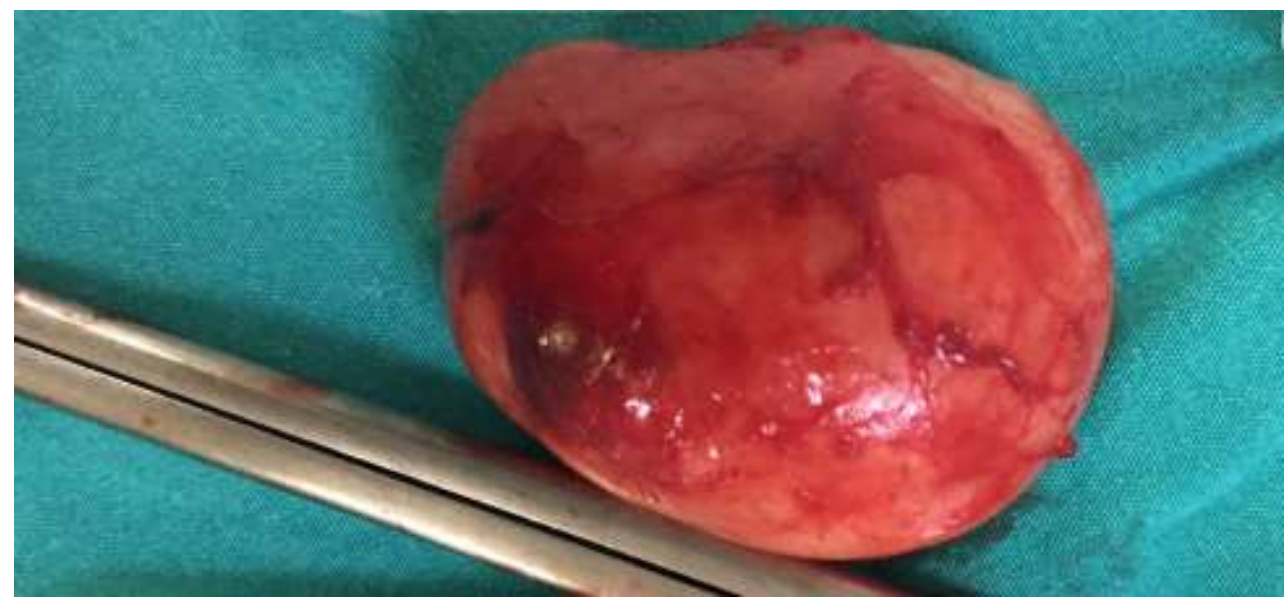

Figure: Surgical excision material. 
From: ${ }^{1}$ Department of Obstetrics and Gynecology, Etlik Zubeyde Hanım, Women's Health Education and Research Hospital, Ankara, Turkey, and ${ }^{2}$ Department of ObstetricsandGynecologhy, Malatya State Hospital

Correspondence: Dr M Cevher Akdulum, Department of Obstetrics and Gynecologhy Etlik Zubeyde Hanım Women's Health Education and Research Hospital, Yeni Etlik Caddesi No:55, Etlik 06010, Keçiören / Ankara, Türkiye. E-mail: fundacevher@gmail.com

Keywords: Bartholin, labiaminora, leiomyoma, vulvar swelling 


\section{REFERENCES}

1. Pandey D, Shetty J, Saxena A, Srilatha PS, Leiomyoma in vulva: a diagnostic dilemma. Case Rep Obstet Gynecol 2014; 2014: 386432.

2. Nielsen GP, Rosenberg AE, Koerner FC, Young RH, Scully RE. Smooth-muscle tumors of the vulva. A clinicopathological study of 25 cases and review of the literature. Am J Surg Pathol 1996; 20: 779-93.

3. Youssef A, Neji K, M'barki M, Ben Amara F, Malek M, Reziga H., Leiomyoma of the vulva. Tunis Med 2013; 91: 78-80.

4. Reyad, MM., M.R. Gazvani, and M.M. Khine, A rare case of primary leiomyoma of the vulva. J Obstet Gynaecol 2006; 26: 73-4.

5. Yazici Yilmaz F ${ }^{1}$, Şengül Ö, Salıhoğlu KN, Dede FS, Dölen I, Ökten H., An unusual location of a vulvar leiomyoma. J Obstet Gynaecol 2015; 35: 210-1. 